\title{
Variability of amino acid digestibility in pigs: inherent factors in feedstuffs and considerations in methodology
}

\author{
W. Sauer ${ }^{1}$, J. He ${ }^{1}$, M.-Z. Fan' ${ }^{2}$ M. Cervantes ${ }^{3}$, A. Kies ${ }^{4}$ and W. Caine ${ }^{5}$ \\ 'Department of Agricultural, Food and Nutritional Science, University of Alberta \\ Edmonton, Alberta, Canada T6G 2P5 \\ ${ }^{2}$ Department of Animal and Poultry Science, University of Guelph \\ Guelph, Ontario, Canada NIG $2 W I$ \\ ${ }^{3}$ ICA-Universidad Autónoma de Baja California, Mexicali, México \\ ${ }^{4} D S M$ Food Specialties, P. O. Box 1, 2600 MA Delft. The Netherlands \\ ${ }^{5}$ Alberta Agriculture, Food and Rural Department, Edmonton, Alberta, Canada B T6H 4P2
}

\begin{abstract}
There is an abundance of information in the literature on apparent ileal amino acid digestibility values in feedstuffs for pigs. In addition to differences in ileal amino acid digestibility values between feedstuffs, there are surprisingly large differences in ileal amino acid digestibility values among different samples of the same feedstuff (in name). In addition to different processing conditions and inherent factors among samples of the same feedstuff, a proportion of the variation can be attributed to different approaches in methodology to determine amino acid digestibility values. It should also be kept in mind that other factors, including the technique used for collection of ileal digesta, may affect, depending on the feedstuff in question, amino acid digestibility values. As far as methodology is concerned, differences in dietary amino acid levels may contribute to the variation in ileal amino acid digestibility values within the same feedstuff. Dietary amino acid levels quadratically affect ileal amino acid digestibility values. In order to remove the effect of dietary amino acid levels, the plateau ileal amino acid digestibility values should be determined. Methods of determination, the direct versus difference versus regression method, can also affect ileal digestibility values within the same feedstuff. In order to estimate this variation, methods of determination specifically suited for different feedstuffs are recommended. As a concluding remark, it is important to take into account the previous considerations when amino acid digestibility values from the literature are compiled for the purpose of reference for diet formulation for pigs.
\end{abstract}

KEY WORDS: ileal digestibility, amino acids, feedstuffs, variation, pigs, methodology 


\section{INTRODUCTION}

Ideal diet formulation should take into account the bioavailability of nutrients in feedstuffs to match the nutrient requirements of animals. As such, the diet will not only provide the best performance at lower cost but also decrease environmental pollution resulting from surplus nutrients, with particular reference to nitrogen and phosphorus.

Bioavailability of amino acids is defined as the proportion of the total amino acids not combined with compounds that interfere with digestion, absorption or utilization for the purpose of maintenance or growth of new tissue (Agriculture Research Council, 1981). Defined as such, availability is an abstract concept, which can not be really measured but only estimated. The growth assay (slope-ratio assay) is the most direct approach to assess the biological availability of amino acids in feedstuffs (e.g., Batterham et al., 1979). Availability values of amino acids, primarily of lysine, have been estimated with the growth assay for various protein supplements in growing pigs (Knabe, 1991; Batterham, 1992). However, many factors including amino acid balance, amino acid intake, energy level, chronology of appearance of absorbed amino acids at the tissue level, genotype and physiological stage can influence amino acid retention and affect results (e.g., Adeola, 1996). In addition, this procedure is time-consuming and expensive, and the availability of only one amino acid can be determined in each assay. When this method is carried out according to a very precise statistical approach and under specific dietary conditions the growth assay may be the only approach to directly verify the validity of other methods to estimate the bioavailability of amino acids.

Amino acid digestibility should not be confused with amino acid availability. Amino acid digestibility is defined as the difference between the amount of amino acids (for each amino acid) in the diet and in faeces or ileal digesta, divided by the amount in the diet (Low, 1982; Sauer and Ozimek, 1986). As was discussed by Sauer et al. (2000), digestibility is likely the most important single determinant of amino acid availability. A large number of studies have been carried out on the topic of amino acid digestibility in pigs during the last three decades. At present, it is well accepted that the ileal rather than faecal analysis method should be used to determine amino acid digestibility values in feedstuffs (e.g., Tanksley and Knabe, 1984; Sauer and Ozimek, 1986). Furthermore, the ileal analysis method is more sensitive than the faecal analysis method for determining differences in amino acid digestibility values as a result of differences in processing (Sauer et al., 1977; Knabe et al., 1989). At this point it should be mentioned that the term, ,amino acid digestibility" is rather absurd (i.e., amino acids are not digested). Unfortunately this term is commonly used.

Apparent ileal digestibility values have been reported for a wide variety of feedstuffs in the literature. It is easy to recognize that there are large differences in ileal 
amino acid digestibility values between feedstuffs. However, it comes somewhat as a surprise to note considerable variation in ileal digestibility values among samples of the same feedstuff (in name). Insofar this variation results from inherent factors and methodology used to determine amino acid digestibility remains to be determined.

Apparent rather than true, real, or standardized ileal amino acid digestibility values are only referred to in this review. Furthermore the different methods for collection of ileal digestion, depending on the feedstuff in question, undoubtedly affect amino acid digestibility values. For discussion on this topic refer to review or studies by Sauer and Ozimek (1986), Leterme et al. (1990), Köhler (1992), Mroz et al. (1996) and Nyachoti et al. (1997).

The objectives of this review are to discuss: 1. some of the inherent factors within feedstuffs responsible for the variation in amino acid digestibility values, and 2 . the effect of approaches in methodology on amino acid digestibility values in feedstuffs.

\section{VARIATION IN APPARENT ILEAL AMINO ACID DIGESTIBILITY VALUES}

There is an abundance of information in the literature on apparent ileal amino acid digestibility values in feedstuffs. In addition to differences in ileal amino acid digestibility values between feedstuffs, there are large differences in ileal amino acid digestibility values among different samples of the same feedstuff. The effect of some of the processing methods and inherent factors on the variation of amino acid digestibility values is discussed for cereal grains, protein supplements, and legume seeds.

\section{Cereal grains}

Cereal grains may contribute a considerable proportion of amino acids to swine diets. The apparent ileal amino acid digestibility values in different samples of cereal grains (e.g., barley, maize and wheat) have been reported. Sauer and Ozimek (1986) and Knabe (1991) summarised the apparent ileal amino acid digestibility values of various cereal grains.

There are substantial differences in ileal amino acid digestibility values among samples of the same cereal grain as reflected by large standard deviations. For example, as summarised by Sauer and Ozimek (1986) for the indispensable amino acids, the differences were relatively large for lysine, methionine and threonine within barley and wheat, ranging from 64.9 to $79.0 \%, 72.1$ to $88.0 \%$ and 64.4 to $76.0 \%$, respectively, in barley and from 62.3 to $81.0 \%, 79.4$ to $92.4 \%$ and 61.9 to $78.4 \%$, respectively, in wheat. 
Some of the differences in ileal amino acid digestibility values may be attributed to differences in processing and other factors including variety of grain, fertilizer application and environmental conditions, which were discussed by Sauer and Ozimek (1986). It is of interest to comment on the effect of processing of cereal grains which may have a large effect on amino acid digestibility values. Increasing the fineness of grinding improved the ileal amino acid digestibilities in wheat (Sauer et al., 1977a) and sorghum (Owsley et al., 1981). Wünsche et al. (1988), in studies with growing pigs prepared with the ileo-rectal anastomosis technique, reported large differences in amino acid digestibility values in barley and wheat as a result of processing (Table 1). For example, the apparent ileal lysine digestibility values in barley were $43.6,54.2$, and $63.0 \%$ in coarsely, medium, and finely ground barley, respectively. In the same order for threonine in barley, these values were $57.7,66.5$ and $72.6 \%$, respectively. The effect of fineness of grinding on amino acid digestibility values was smaller in wheat than in barley. For example, the apparent ileal lysine digestibility values were $49.4,50.6$, and $56.4 \%$ in coarsely, medium, and finely ground wheat, respectively.

The effect of fibre content in wheat on apparent ileal amino acid digestibility values was recently investigated by Fan et al. (2001). The digestibility values of lysine and threonine (first- and second-limiting amino acids) in six samples of

TABLE 1

The effect of fineness of grinding on the apparent ileal digestibilities (\%) of lysine, methionine, threonine, and tryptophan in barley and wheat (Wünsche et al., 1987)

\begin{tabular}{lccc}
\hline & \multicolumn{3}{c}{ Barley } \\
\cline { 2 - 4 } Items & coarse & medium & fine \\
\cline { 2 - 4 } & $(51 / 38 / 11)^{\mathrm{a}}$ & $(1 / 53 / 46)$ & $(0.6 / 43 / 56)$ \\
\hline Lysine & $43.6 \pm 13.1^{\mathrm{b}}$ & $54.2 \pm 8.1$ & $63.0 \pm 5.4$ \\
Methionine & $67.3 \pm 8.5$ & $72.2 \pm 3.6$ & $78.2 \pm 1.4$ \\
Threonine & $57.7 \pm 6.6$ & $66.5 \pm 2.8$ & $72.6 \pm 2.5$ \\
Tryptophan & $58.0 \pm 4.6$ & $68.1 \pm 5.4$ & $72.0 \pm 0.6$ \\
& & & \\
\cline { 2 - 4 } & & Wheat & fine \\
\cline { 2 - 4 } & & medium & $(0 / 35 / 65)$ \\
\hline Items & $(26 / 42 / 32)$ & $(1 / 38 / 61)$ & $56.4 \pm 5.0$ \\
Lysine & $49.4 \pm 5.8$ & $50.6 \pm 11.7$ & $82.9 \pm 4.2$ \\
Methionine & $75.2 \pm 3.3$ & $82.6 \pm 4.2$ & $70.6 \pm 3.7$ \\
Threonine & $64.2 \pm 3.9$ & $65.7 \pm 8.9$ & $81.0 \pm 3.0$ \\
Tryptophan & $75.2 \pm 3.5$ & $78.2 \pm 5.1$ & \\
\hline
\end{tabular}

${ }^{3}$ percentage of particle sizes (sieve analysis): $>2 \mathrm{~mm}<2 \mathrm{~mm}$ to $1 \mathrm{~mm}<1 \mathrm{~mm}$

${ }^{b}$ mean and standard deviation (barley: $n=3$ or 4 ; wheat: $n=5$ or 7 ) 
wheat were lowest $(\mathrm{P}<0.05)$ and ranged from 59.0 to $70.3 \%(\mathrm{P}<0.05)$ and 64.2 to $73 \%(\mathrm{P}<0.05)$, respectively. The digestibility values of these amino acids (and most of the others) were negatively correlated $(\mathrm{P}<0.05)$ with the neutral-detergent fibre content which ranged from 114 to $172 \mathrm{~g} \mathrm{~kg}^{-1}$.

More information on variation in ileal amino acid digestibility values within cereal grains include studies with wheat (hard vs soft) by Ivan and Farrell (1976), barley and wheat by Sauer et al. (1981), and barley by Buraczewska et al. (1987).

\section{Protein supplements}

Many studies have been carried out to determine amino acid digestibility values in protein supplements. These values were summarised by Sauer and Ozimek (1986), Knabe et al. (1989) and Knabe (1991). There were large differences in ileal amino acid digestibility values among samples of the same protein supplement, although the range of variation within protein supplements was smaller than in cereal grains. The variation in ileal amino acid digestibility values was highest in samples of cottonseed meal, fish meal, meat-and-bone meal and peanut meal, and smallest in blood meal (except for isoleucine), canola meal, soyabean meal and sunflower meal. This variation was particularly evident for lysine, methionine, and threonine. For example, the lysine, methionine and threonine digestibility values in different samples of soyabean meal ranged from 80.1 to $90.7 \%, 74.5$ to $96.7 \%$ and 70.7 to $82.2 \%$, respectively. The isoleucine digestibility values in samples of blood meal samples and tryptophan in meat-and-bone meal showed the largest differences, ranging from 60 to $80 \%$, and 35 to $65 \%$, respectively, which, as will be discussed later, can be in part explained by methodological approaches to determine amino acid digestibility values.

As is well known, there is considerable variation in amino acid digestibility values in samples of meat-and-bone meal as was illustrated in studies by Knabe et al. (1989; Table 2). Of the indispensable amino acids, the values ranged from 73 to $86 \%$ for arginine (smallest range) to 35 to $65 \%$ for tryptophan (largest range). Knabe et al. (1989) attributed this variation to differences in the source of raw material and/or processing methods, although processing appeared to have the more noticeable effect. The digestibility values in meat-and-bone meal prepared with the newer processes, which utilize less heat, were approximately 10 percentage units higher than those prepared with the older methods. The adverse effect in pig performance caused by excessive heating during processing of meatand-bone meal was also demonstrated by Batterham et al. (1986) in amino acid availability studies.

With respect to protein supplements of plant origin, in addition to differences in processing conditions (e.g., for soyabean meal; Huisman et al., 1988) differences in digestibility values between different samples may also arise from other factors. 
TABLE 2

Range and means of apparent ileal crude protein and digestibilities (\%) of the indispensable amino acids in nine meat-and-bone meals (Knabe et al., 1989)

\begin{tabular}{lcc}
\hline & Range & Means $^{\mathrm{a}}$ \\
\hline Crude protein & $57-75$ & $67 \pm 0.4$ \\
Amino acids & $73-86$ & $81 \pm 0.5$ \\
Arginine & $53-74$ & $66 \pm 0.6$ \\
Histidine & $55-81$ & $70 \pm 0.7$ \\
Isoleucine & $63-82$ & $74 \pm 0.5$ \\
Leucine & $56-80$ & $70 \pm 0.4$ \\
Lysine & $70-85$ & $78 \pm 0.4$ \\
Phenylalanine & $51-75$ & $64 \pm 0.6$ \\
Threonine & $35-65$ & $54 \pm 1.0$ \\
Tryptophan & $60-80$ & $73 \pm 0.4$ \\
Valine & & \\
\hline
\end{tabular}

mean and standard error $(n=5)$

For example, differences in digestibility values in canola meal may result from different fibre levels (Fan et al., 1996). In this study, the ileal digestibility values of most amino acids were negatively correlated $(\mathrm{P}<0.05)$ with the neutral-detergent fibre content. For example, the apparent ileal digestibility values of lysine and threonine increased from 68.3 to $76.7 \%$, and 59.7 to $66.5 \%$, respectively, as the neutral-detergent fibre content in six samples of canola meal from western-Canada decreased from 24.9 to $19.3 \%$.

More information of variation in amino acid digestibility values within protein supplements include studies with soyabean meal, fish meal, peanut meal, and sunflower meal by Knabe et al. (1989).

Legume seeds

Legume seeds such as peas, field beans and lupins, which can provide a rich protein and energy source for swine diets, are used more and more in swine diets, especially peas. Legume seeds contain variable amounts of protease inhibitors, tannins, and lectins. These antinutritional factors have in common that they exert detrimental effects on the digestive and/or absorptive processes.

The evaluation of the nutritive value in pigs for these ingredients is receiving a lot of attention at present. The apparent ileal amino acid digestibility values in legume seeds, mainly in peas, were summarised by Gatel (1992). There were considerable differences in ileal amino acid digestibility values among different pea samples. Of the indispensable ( + semi-) amino acids, the differences were relatively large for cysteine, methionine, threonine and tryptophan, ranging from 44.0 to 
$85.0 \%, 58.0$ to $80.7 \%, 56.8$ to $92.1 \%$ and 46.6 to $78.0 \%$, respectively. As discussed by Gatel (1992), differences in processing conditions, antinutritional factors and other factors associated with variety and growing conditions were only, in part, responsible for the large variation. Fan and Sauer (1999) recently determined the ileal amino acid digestibility values in six samples of peas which originated from various locations in western-Canada. Of the indispensable (+ semi-) amino acids within each sample, the ileal digestibility values of arginine and lysine were relatively high, ranging from 88.3 to $91.3 \%$ and from 78.7 to $85.2 \%$, respectively, while the digestibility values of cysteine, methionine and tryptophan were relatively low, ranging from 53.8 to $62.7 \%, 69.4$ to $75.4 \%$, and from 53.1 to $70.4 \%$, respectively. The ileal digestibility values of most of the indispensable amino acids $(+$ semi-) were negatively correlated $(\mathrm{P}<0.05)$ with the neutral-detergent fibre content in the pea samples which ranged from 14.6 to $18.2 \%$. Of the amino acids, only the digestibility values of tryptophan was negatively correlated $(\mathrm{P}<0.05)$ with the trypsin inhibitor activity in the pea samples. Other studies by Fan et al. (1994), in which the digestibility of tryptophan was not measured, also showed no correlation between trypsin inhibitor activity and ileal amino acid digestibility values in six pea samples.

It is also of interest to comment on a study by Huisman et al. (1988) with beans (Phaseolus vulgaris). Crude protein digestibilities were $-36.1,8.3$, and $37.3 \%$ in beans heated for 20,40 , and $60 \mathrm{~min}$, respectively. The increase in digestibility was accompanied by a decease in lectin content. Amino acid digestibility values were not reported in this study, but would be expected to follow the same pattern as crude protein digestibility. The mode of action of lectins and their effect on protein digestion and amino acid absorption were discussed in detail by Huisman (1989).

More information on inherent factors affecting the variation in digestibility values in legumes include studies with peas by Buraczewska et al. (1989), Gatel and Grosjean (1990), Leterme et al. (1990), and Gdala et al. (1992), and with fababeans by Grala et al. (1993), and by Flis et al. (1999).

\section{METHDOLOGICAL SOURCES OF VARIATION}

As was discussed previously, there are large differences in the apparent ileal digestibility values of amino acids among samples of the same feedstuff. These differences decrease the sensitivity and liability of apparent ileal amino acid digestibility values for assessing amino acid availability between different feedstuffs and cause inaccuracy in the diet formulation for swine. This variation may misrepresent the real variation among samples of the same feedstuff (in name), as methodological factors are responsible for a certain proportion, in addition to inherent factors such as for instance differences in the neutral-detergent fibre 
content among samples of the same feedstuff. The major responsible methodological factors, those including dietary amino acid levels and methods of determination, will be addressed.

\section{The effect of dietary amino acid level}

As was illustrated by Eggum (1973) in studies with rats, the apparent faecal crude protein digestibility in soyabean meal increased curvilinearly with increasing dietary crude protein content. Similarly, it is expected that apparent ileal amino acid digestibility values will increase curvilinearly with increasing amino acid contents in the assay diet. Therefore, values for apparent ileal amino acid digestibility are only meaningful and valid under strictly standardized conditions, at least with respect to the amino acid content in the assay diet. Examination of the literature reveals that, in many instances, this has not been the case. The determination of apparent ileal digestibility values of amino acids were performed at various dietary amino acid levels as indicated by differences in dietary crude protein content. For example, the crude protein contents in maize starch-based diets were 140 and $210 \mathrm{~g} \mathrm{~kg}^{-1}$, respectively, in studies by Holmes et al. (1974), and Jørgensen et al. (1984). In the same order for these diets, the apparent ileal lysine digestibilities were 80 and $91 \%$, respectively. Differences in crude protein and amino acid content in the assay diets may explain, in part, the variation in apparent ileal amino acid digestibility values among different samples of the same feedstuffs (e.g., Sauer and Ozimek, 1986).

Studies reported by Fan et al. (1994) with maize starch-based soyabean meal diets showed that there were large increases $(\mathrm{P}<0.01)$ in apparent ileal digestibility values of crude protein and all amino acids when the dietary crude protein content was increased from 40 to $240 \mathrm{~g} \mathrm{~kg}^{-1}$. For crude protein, the increase was 26.7 percentage units. Of the indispensable amino acids, the increases ranged from 11.8 percentage units for phenylalanine to 30.9 percentage units for threonine. The increases in apparent ileal digestibility values of amino acids were greatest at the lower crude protein levels; the increases became negligible at the higher crude protein levels as endogenous amino acids account for a smaller proportion of total amino acids in ileal digesta (Fan et al., 1994).

The determination of the quadratic relationships between amino acid digestibility values and the amino acid content and the plateau digestibility values were analysed according to a segmented quadratic with plateau model (Fan et al., 1994). The quadratic with plateau relationships between the ileal digestibility values and dietary content are illustrated in Figure 1 for leucine and methionine. A similar pattern was observed for the other amino acids. Initially, the apparent ileal crude protein and amino acid digestibility values increased sharply; thereafter the increases became smaller and reached their plateau values after which there were no 

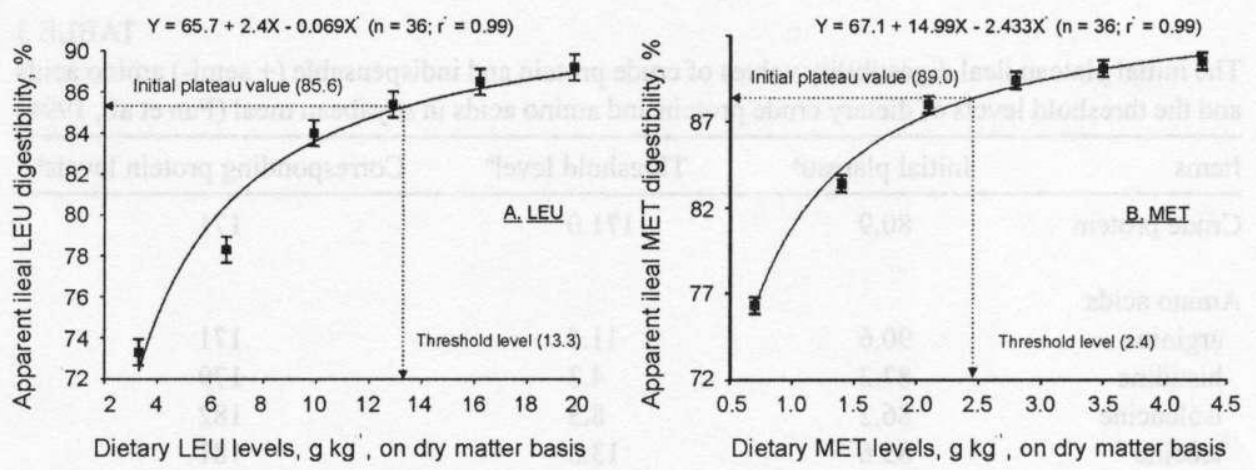

Figure 1. The quadratic with plateau relationships between apparent ileal amino acid digestibility values (Y: \%) and dietary amino acid contents (X: \%). A. Leucine (LEU); B. Methionine (MET) (Fan et al., 1994)

further increases and the digestibility values became independent of the dietary amino acid levels. The lower endpoints of $95 \%$ confidence intervals of the plateau digestibility values are defined to be the initial plateau digestibility values. The dietary crude protein and amino acid contents, corresponding to the initial plateau digestibility values, are referred to as the dietary threshold levels. The initial plateau ileal digestibility values and the corresponding threshold levels of crude protein and indispensable ( + semi-) amino acids are presented in Table 3.

As illustrated in Figure 2 for crude protein, methionine, threonine and tyrosine, the apparent ileal digestibility values of crude protein and amino acids did not reach their initial plateau values simultaneously at the same dietary crude protein content. This shows that the dietary amino acid content affects apparent ileal amino acid digestibility values, irrespective of the dietary crude protein content. Therefore, to obtain the plateau values, the level of inclusion of a feedstuff in the assay diet should be such that the amino acid contents in the assay diet are equal to or exceed the corresponding threshold levels. This consideration is especially important for the determination of the digestibility values of the limiting amino acids (Fan et al., 1994).

Differences in dietary amino acid levels are responsible for the variation in ileal amino acid digestibility values within the same feedstuff. As discussed previously, there is considerable variation in apparent ileal digestibility values of amino acids within each cereal grain. Of the indispensable amino acids, the variation is especially large for lysine and threonine. The determination of apparent ileal digestibility values of amino acids in low-protein feedstuffs is routinely carried out with the direct method in which the test feedstuff provides the sole amino acids in the assay diet. However, the total contents of crude protein and the majority of the amino acids in cereal grains are usually below the threshold levels (Sauer et al., 2000). 
TABLE 3

The initial plateau ileal digestibility values of crude protein and indispensable (+ semi-) amino acids and the threshold levels of dietary crude protein and amino acids in soyabcan meal (Fan et al., 1994)

\begin{tabular}{lccc}
\hline Items & Initial plateau $^{\mathbf{a}}$ & Threshold level $^{\mathbf{b}}$ & Corresponding protein levels $^{\mathbf{c}}$ \\
\hline Crude protein & 80.9 & 171.0 & 171 \\
& & & \\
Amino acids & & & 171 \\
arginine & 90.6 & 11.5 & 179 \\
histidine & 87.2 & 4.3 & 182 \\
isolcucine & 86.2 & 8.3 & 181 \\
leucine & 85.6 & 13.3 & 163 \\
lysine & 86.0 & 9.4 & 152 \\
methionine & 89.0 & 2.4 & 159 \\
cysteine & 78.5 & 2.4 & 163 \\
phenylalanine & 87.9 & 8.2 & 181 \\
tyrosine & 87.6 & 6.2 & 173 \\
threonine & 77.0 & 6.3 & 183 \\
valine & 83.7 & 8.4 & 1109 \\
\hline
\end{tabular}

a lower endpoints of $95 \%$ confidence intervals at the estimated plateau ileal digestibility values

b $\mathrm{g} \mathrm{kg}^{-1}$, dry matter basis

" the dietary levels of crude protein ( $\mathrm{g} \mathrm{kg}^{-1}$, dry matter basis) corresponding to the threshold levels of each amino acid

As a result, small differences in dietary contents of crude protein and amino acids below the threshold levels will result in relatively large variations in the digestibility values of amino acids, especially those amino acids present at low levels in cereal grains (lysine, threonine and tryptophan) and/or amino acids of which the ileal endogenous recovery is relatively high (e.g., threonine), as illustrated in Figure 1.

\section{The effect of methods for determination}

There are three methods for the determination of apparent ileal amino acid digestibility values in feedstuffs.

1. The direct method. The assay diet is formulated in such a manner that the assay feed ingredient provides the only amino acids in the diet. Therefore, amino acid digestibility values in the assay feed ingredient are equal to the corresponding value in the assay diet. If the assay diet is maize starch-based a correction is sometimes made for amino acid losses associated with the feeding of maize starch per se. 


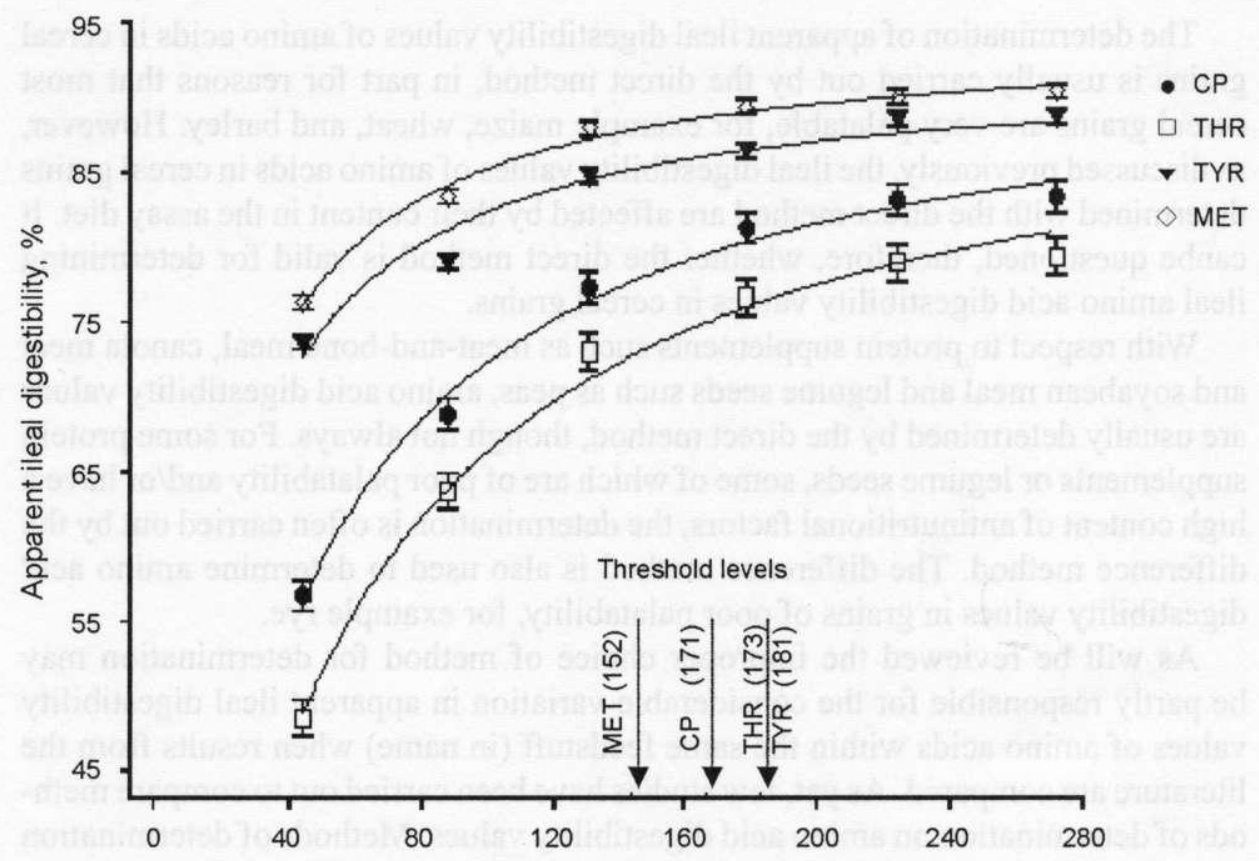

Dietary CP levels, $\mathrm{g} \mathrm{kg}$, on dry matter basis

Figure 2. The quadratic with plateau relationships between the apparent ileal crude protein and amino acid digestibility values (means $\pm \mathrm{SE}$ ) and the dietary crude protein content. $\mathrm{CP}$ : crude protein; MET: methionine; THR: threonine; TYR: tyrosine (Fan et al., 1994)

2. The difference method. This method involves the formulation of both a basal and an assay diet. The basal diet contains the basal feed ingredient which provides the only amino acids in the diet. The assay diets consist of a mixture of the basal feed ingredient and the assay feed ingredient. The amino acid digestibility values in the assay feed ingredient can then be determined by the difference. It is assumed that there is no interaction in nutrient digestibility between the basal and the assay feed ingredient.

3. The regression method. This method evaluates the basal and assay feed ingredient simultaneously. Both the basal and the assay feed ingredient provide the only amino acids in the diets. The ingredients are mixed at various graded levels and more than two assay diets are formulated. By aid of regression analysis one can calculate the amino acid digestibility values of the assay feed ingredients (and also of the basal feed ingredient). As for the difference method, it is assumed there is no interaction between the basal and assay feed ingredient. 
The determination of apparent ileal digestibility values of amino acids in cereal grains is usually carried out by the direct method, in part for reasons that most cereal grains are very palatable, for example maize, wheat, and barley. However, as discussed previously, the ileal digestibility values of amino acids in cereal grains determined with the direct method are affected by their content in the assay diet. It canbe questioned, therefore, whether the direct method is valid for determining ileal amino acid digestibility values in cereal grains.

With respect to protein supplements such as meat-and-bone meal, canola meal and soyabean meal and legume seeds such as peas, amino acid digestibility values are usually determined by the direct method, though not always. For some protein supplements or legume sceds, some of which are of poor palatability and/or have a high content of antinutritional factors, the determination is often carried out by the difference method. The difference method is also used to determine amino acid digestibility values in grains of poor palatability, for example rye.

As will be reviewed the improper choice of method for determination may be partly responsible for the considerable variation in apparent ileal digestibility values of amino acids within the same feedstuff (in name) when results from the literature are compared. As yet, few studies have been carried out to compare methods of determination on amino acid digestibility values. Methods of determination for amino acid digestibility values will be discussed for cereal grains, protein supplements, legume seeds, and other feedstuffs, including by-products. In addition, a small discussion is devoted to possible interactions between feedstuffs.

\section{Cereal grains}

As an example of a cereal grain, the apparent ileal amino acid digestibility values were determined in barley by the direct, difference, and regression methods in studies with five barrows fitted with a simple T-cannula at the distal ileum (Fan and Sauer, 1995a). The barrows were fed five diets according to a $5 \times 5$ Latin square design. Diet 1 was a maize starch-based canola meal diet. Canola meal supplied the sole source of amino acids. Diets 2, 3 and 4 contained 225, 450 and $675 \mathrm{~g} \mathrm{~kg}^{-1}$ barley, respectively, and 366,305 and $244 \mathrm{~g} \mathrm{~kg}^{-1}$ canola meal, respectively. Diet 5 contained $900 \mathrm{~g} \mathrm{~kg}^{-1}$ barley, which was the sole source of amino acids. Except for diet 5, the diets contained $160 \mathrm{~g} \mathrm{~kg}^{-1}$ crude protein.

There were increases $(\mathrm{P}<.05)$ in the digestibility values of the majority of the amino acids in barley as its level of inclusion in the diets was increased from 225 to $675 \mathrm{~g} \mathrm{~kg}^{-1}$ (Fan and Sauer, 1995a). Of the indispensable amino acids, the increase was largest for lysine, 23.5 to $61.3 \%$, and smallest for phenylalanine, 56.8 to $72.1 \%$. Among the amino acids, lysine and phenylalanine from barley contributed the lowest and highest percentage to the dietary content, respectively. These results show that, at the lower levels of inclusion, the digestibility values in barley are underestimated 
with the difference method. The underestimation is greater for amino acids that are present in small amounts in barley, which often include the limiting amino acids, as was illustrated in this case for lysine. Furthermore, there were large decreases in the standard errors of the amino acid digestibility values as the level of inclusion of barley was increased from 225 to $675 \mathrm{~g} \mathrm{~kg}^{-1}$. Therefore, the values obtained at the dietary inclusion level of $675 \mathrm{~g}$ barley $\mathrm{kg}^{-1}$ can be considered most accurate.

Based on the aforementioned study, it is evident that the reliability of the determination of the apparent ileal digestibility values of amino acids with the difference method is dependent on the contribution of amino acids in the assay feedstuff to their total dietary contents. The higher the contribution of a particular amino acid to the total dietary content, the more reliable the measurement of its digestibility with the difference method.

A linear regression model was used to describe the relationships between the digestibility values in diets $1,2,3$, and 4 and the contribution levels of amino acids in canola meal to these diets (Fan and Sauer, 1995a). Intercepts of the linear regression equations provided the estimated apparent ileal digestibility values of amino acids in barley. The principle for determining apparent ileal amino acid digestibility values in the assay feed ingredient (barley) is illustrated in Figure 3 with lysine as an example. Linear relationships and corresponding digestibility values in barley could not be obtained ( $\mathrm{P}>0.05$ ) for isoleucine, leucine, phenylalanine, threonine, and valine; differences in digestibility values of these amino acids between barley and canola meal were not large enough to create linear responses. Therefore, in order to apply the regression method successfully to all amino acids, it is necessary that there are sufficiently large differences in the digestibility values of all amino acids between the two feedstuffs. To our knowledge, this is the first time that the regression method was used for the determination of ileal amino acid digestibility values in feedstuffs for swine.

Among the three methods, the regression method is, in principle, the most accurate. The apparent ileal digestibility values of crude protein and the indispensable amino acids are considered to be the most precise values for evaluating the results obtained by the other two methods (Sauer et al., 2000). The apparent ileal digestibility values of the indispensable amino acids in barley, determined with the direct, difference, and regression methods, are presented in Table 4 . For the difference method, the digestibility values for barley, determined at the inclusion level of $675 \mathrm{~g} \mathrm{~kg}^{-1}$ were used for comparison. As was mentioned previously, these digestibility values were associated with the smallest standard errors and therefore considered most precise. At this level of inclusion, there were no differences $(\mathrm{P}>0.05)$ between digestibility values of amino acids in barley determined by the difference and regression methods. This shows that the difference method is only reliable when the inclusion levels of the amino acids from the assay ingredient in the diets are high. Furthermore, the ileal digestibility values of crude protein and amino 


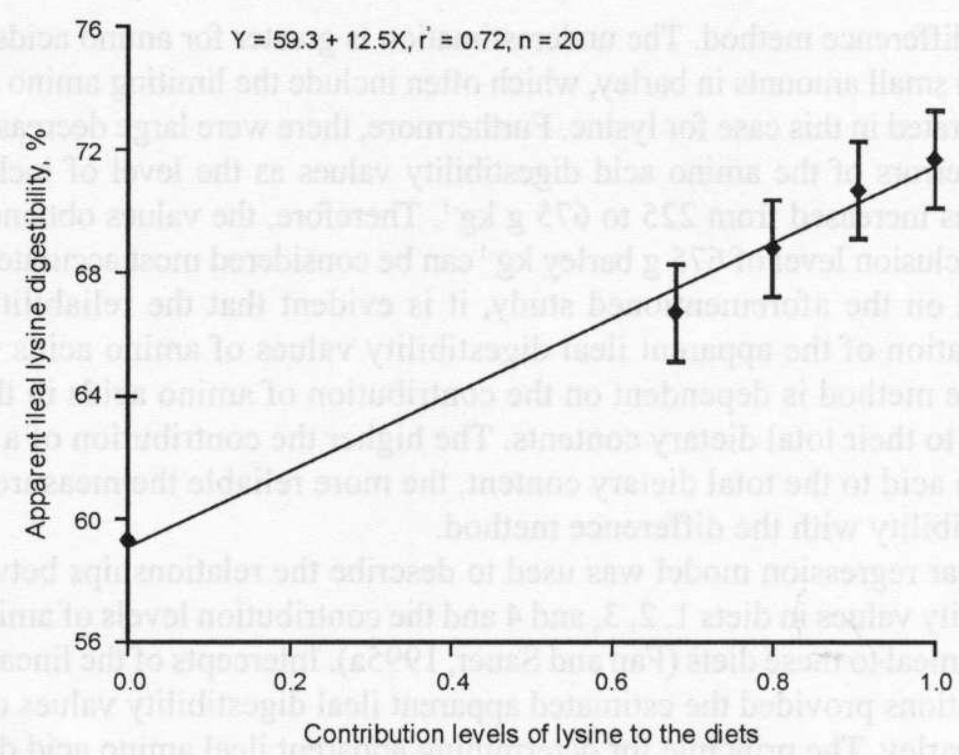

Figure 3. Estimation of the apparent ileal digestibility of lysine in the assay feed ingredient (barley) by linearly regressing the ileal digestibility values (Y: \%) of lysine in the assay diets against the contribution levels (X: decimal percentage) of lysine from the basal feed ingredient (canola meal) to its content in the assay diets (Fan and Sauer, 1995a)

TABLE 4

Comparison of the apparent ileal digestibility values ${ }^{a}(\%)$ of crude protein and indispensable amino acids in barley by the direct, the difference and the regression methods (Fan and Sauer, 1995a)

\begin{tabular}{lccc}
\hline \multirow{2}{*}{ Items } & \multicolumn{3}{c}{ Method of determination } \\
\cline { 2 - 4 } & direct method & difference method $^{\mathrm{b}}$ & regression method \\
\hline $\begin{array}{l}\text { Number of observations } \\
\text { Crude protein }\end{array}$ & 5 & 5 & 20 \\
Amino acids & $56.6 \pm 1.88$ & $58.9 \pm 3.36$ & $57.7 \pm 2.83$ \\
arginine $^{\mathrm{c}}$ & & & \\
histidine $^{\text {isoleucine }}$ & $64.7 \pm 1.93$ & $69.8 \pm 3.15$ & $68.4 \pm 2.39$ \\
leucine & $69.5 \pm 2.68$ & $71.9 \pm 3.56$ & $70.5 \pm 2.27$ \\
lysine & $61.1 \pm 3.29$ & $66.9 \pm 4.80$ & - \\
phenylalanine & $66.6 \pm 2.80$ & $70.3 \pm 3.79$ & - \\
threonine & $54.1 \pm 4.18$ & $61.3 \pm 4.93$ & $59.3 \pm 4.65$ \\
valine & $69.6 \pm 3.41$ & $72.1 \pm 4.28$ & - \\
\hline
\end{tabular}

a mean and standard error

${ }^{b}$ digestibility values calculated from diet $4\left(675 \mathrm{~g}\right.$ barley $\left.\mathrm{kg}^{-1}\right)$

c means in the same row show a trend to increase ( $\mathrm{P}<0.10$, by one-tailed student's $t$-test)

d,e means in the same row with different superscript letters differ $(P<0.05)$ 
acids determined by the difference and regression method were usually higher $(\mathrm{P}<0.05$ or 0.10$)$ than those determined by the direct method.

These results suggest that the direct method is not suitable for the determination of apparent ileal digestibility values of amino acids in feedstuffs, such as barley. This results from the fact that the endogenous amino acid contribution is relatively high at a low dietary amino acid intake. As was demonstrated by Fan et al. (1994), there are quadratic with plateau relationships between the dietary amino acid levels and their respective apparent ileal digestibility values.

\section{Protein supplements}

As an example of a protein supplement, the apparent values were determined in canola meal with the direct, difference and regression methods. This information was obtained in the same expcriment as described under cereal grains, in which barley was considered the assay feed ingredient and canola meal the basal feed ingredient.

There were increases in the digestibility values of the majority of the amino acids in canola meal as its level of inclusion in the diet was increased from 244 to $366 \mathrm{~g} \mathrm{~kg}^{-1}$ (Fan and Sauer, 1995a). Of the indispensable amino acids, the increase in contribution was smallest for lysine, from 67.9 to $90.5 \%$, and largest for phenylalanine, from 49.4 to $81.5 \%$. The digestibility values of most of the amino acids were higher $(\mathrm{P}<0.05)$ when these were determined by difference from the diet with the lowest level of inclusion ( $\left.244 \mathrm{~g} \mathrm{~kg}^{-1}\right)$ of canola meal. At first, these results seemed contradictory to our expectations. However, the digestibility values in canola meal were determined by difference using the digestibility values in barley determined with the direct method. As was shown previously, the direct method underestimated the digestibility values in barley. As a result, the digestibility values in canola meal were overestimated when these were determined by difference from the diet with its lowest level of inclusion. However, if valid digestibility values of amino acids in barley (675 $\mathrm{g} \mathrm{kg}^{-1}$ inclusion) are used to determine the digestibility values in canola meal ( $244 \mathrm{~g} \mathrm{~kg}^{-1}$ inclusion), then values similar to those determined from the other inclusion levels ( 305 and $366 \mathrm{~g} \mathrm{~kg}^{-1}$ ) will be obtained. Furthermore, there were no differences $(\mathrm{P}>0.05)$ in the digestibility values of amino acids in canola meal when these were calculated from the diets that contained 305 and $366 \mathrm{~g} \mathrm{~kg}^{-1}$ canola meal; at these levels of inclusion the overestimation in amino acid digestibility values was eliminated. In addition, there were large decreases in the standard errors of the amino acid digestibility values as the dietary inclusion level of canola meal was increased from 244 to $366 \mathrm{~g} \mathrm{~kg}^{-1}$. These results show once more that the determination of the apparent ilcal digestibility values of amino acids with the difference method is dependent on the contribution of amino acids in the assay feedstuff to their total dietary content. 
For measurement of the apparent ileal digestibility values of amino acids in canola meal with the regression method, linear relationships between the digestibility values in diets $1,2,3$, and 4 and the contribution levels of amino acids in barley to the diets were established (Fan and Sauer, 1995a). Intercepts of the linear regression equations provided the estimated apparent ileal digestibility values of amino acids in canola meal. The principle for determining apparent ileal amino acid digestibility values in the assay feed ingredient (canola meal) is illustrated in Figure 4 with arginine as an example. For the same reasons explained previously, linear relationships and the corresponding digestibility values in canola meal could not be obtained $(\mathrm{P}>0.05)$ for some amino acids, including isoleucine, leucine, phenylalanine, threonine, and valine.

The apparent ileal digestibility values of the indispensable (+ semi-) amino acids in canola meal determined with the direct, difference, and regression methods are presented in Table 5. With the difference method, the digestibility values for canola meal determined at the inclusion level of $366 \mathrm{~g} \mathrm{~kg}^{-1}$ were referred to. These digestibility values were associated with the smallest standard errors. There were no differences $(\mathrm{P}>0.05)$ in the digestibility values of amino acids in canola meal when these were determined with the different methods. These results sug-

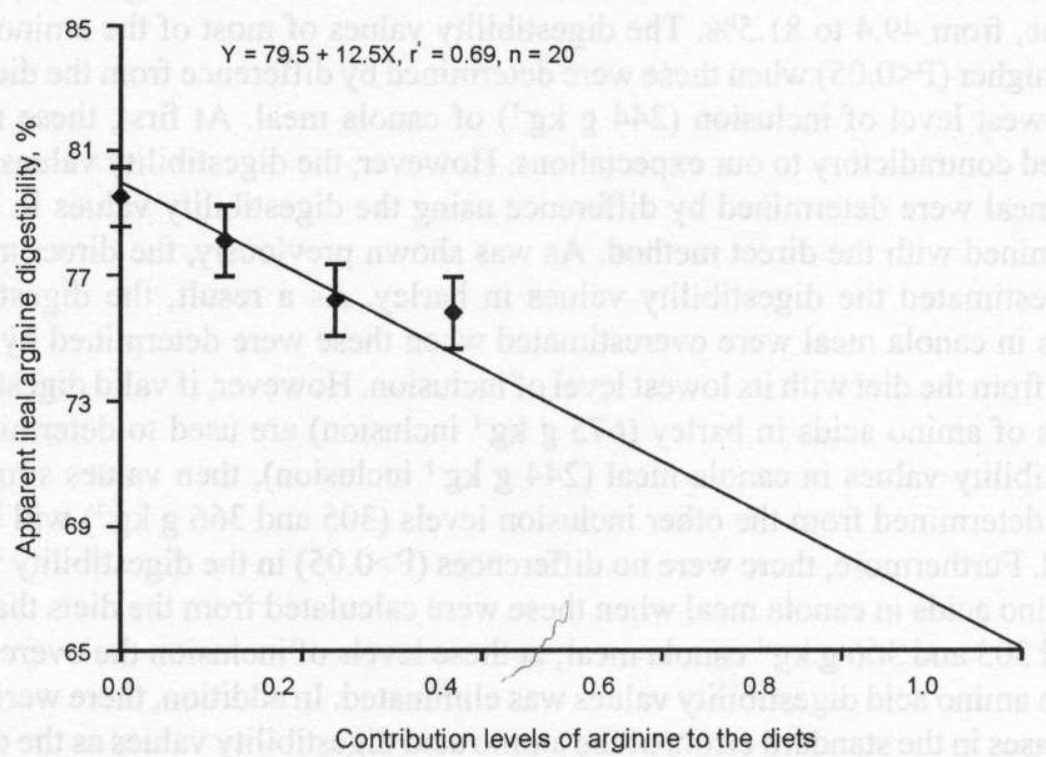

Figure 4. Estimation of the apparent ileal digestibility of arginine in the assay feed ingredient (canola meal) by linearly regressing the ileal digestibility values (Y: $\%$, means $\pm \mathrm{SE})$ of arginine in assay diets against the contribution levels (X: decimal percentage) of arginine from the basal feed ingredient (barley) to its content in the assay diets (Fan and Sauer, 1995a) 
TABLE 5 Determination of the apparent ileal digestibility values ${ }^{a}(\%)$ of crude protein and indispensable amino acids in canola meal by the direct, the difference and the regression methods (Fan and Sauer, 1995a)

\begin{tabular}{lccc}
\hline \multirow{2}{*}{ Items } & \multicolumn{3}{c}{ Method of determination } \\
\cline { 2 - 4 } & direct method & difference method & regression method \\
\hline $\begin{array}{l}\text { Number of observations } \\
\text { Crude protein }\end{array}$ & 5 & 5 & 20 \\
& $66.0 \pm 0.85$ & $62.5 \pm \mathrm{I} .44$ & $64.3 \pm 1.46$ \\
Amino acids & & & \\
arginine & $80.8 \pm 1.19$ & $79.4 \pm 1.14$ & $79.5 \pm 0.95$ \\
histidine & $80.0 \pm 0.78$ & $77.4 \pm 1.19$ & $78.7 \pm 1.09$ \\
isoleucine & $69.3 \pm 0.77$ & $65.3 \pm 1.58$ & - \\
leucine & $70.8 \pm 1.15$ & $67.7 \pm 1.68$ & - \\
lysine & $73.7 \pm 0.79$ & $70.7 \pm 1.10$ & $71.8 \pm 1.38$ \\
phenylalanine & $70.8 \pm 1.18$ & $67.9 \pm 1.90$ & - \\
tyrosine & $66.0 \pm 0.81$ & $64.5 \pm 1.53$ & $64.5 \pm 1.49$ \\
threonine & $63.1 \pm 0.88$ & $60.7 \pm 1.64$ & - \\
valine & $67.5 \pm 0.84$ & $63.8 \pm 1.72$ & - \\
\hline
\end{tabular}

${ }^{a}$ mean and standard error

${ }^{b}$ digestibility values calculated from diet 2 (366 g canola meal $\left.\mathrm{kg}^{-1}\right)$

gest that the apparent ileal digestibility values of amino acids in high-protein feedstuffs, such as canola meal, can be determined with either method, including the difference method when its dietary inclusion level is relatively high.

\section{Legume seeds}

As an example of a legume seed, the apparent ileal amino acid digestibility values were determined in peas by the direct, difference, and regression methods (Fan and Sauer, 1995b). Five growing barrows, fitted with a simple T-cannula at the distal ileum, were fed five diets according to a $5 \times 5$ Latin square design. Diet 1 contained $885 \mathrm{~g}$ wheat $\mathrm{kg}^{-1}$. Wheat provided the sole source of amino acids in this diet. In diets 2, 3 and 4, peas were included at three levels at the expense of wheat and maize starch, 168, 336 and $504 \mathrm{~g} \mathrm{~kg}^{-1}$, respectively. Diet 5, which was maize starch-based, contained $671 \mathrm{~g}$ peas $\mathrm{kg}^{-1}$ providing the sole source of amino acids in this diet. All diets were formulated to contain $160 \mathrm{~g}$ crude protein $\mathrm{kg}^{-1}$. A detailed description of this experiment was provided by Fan and Sauer (1995b).

There were no differences $(\mathrm{P}>0.05)$ in ileal digestibility values of crude protein and amino acids in peas determined by the difference method between the three inclusion levels (168, 336 and $504 \mathrm{~g}$ peas kg $^{-1}$ diet) (Fan and Sauer, 1995b). 
The ileal digestibility values in peas were higher at the high $\left(504 \mathrm{~g} \mathrm{~kg}^{-1}\right.$ diet $)$ than at the low (168 g kg-1 diet) level of inclusion. Also, as the level of inclusion of peas in the diets was increased, there was a decrease in the standard errors of the means for the ileal digestibility values. Once more, these results show that the accuracy of determination of apparent ileal amino acid digestibility values by the difference method is dependent on the inclusion level of the assay feed ingredient in the assay diet.

Linear relationships were established by the regression method between the apparent ileal digestibility values of peas in the diets (diets 2, 3, 4, and 5) and the contribution levels of crude protein and amino acids from the basal feed ingredient (wheat) to the diets (Fan and Sauer, 1995b). Of the indispensable (+ semi-) amino acids, the linear relationships were not significant $(\mathrm{P}>0.05)$ for histidine, threonine and valine due to the fact that the differences in apparent ileal digestibility values of these amino acids between the assay (peas) and the basal feed ingredient (wheat) were not large enough to create linear variations. The principle for determining apparent ileal amino acid digestibility values in the assay feed ingredient (peas) by the regression method is illustrated in Figure 5 with cysteine as example.

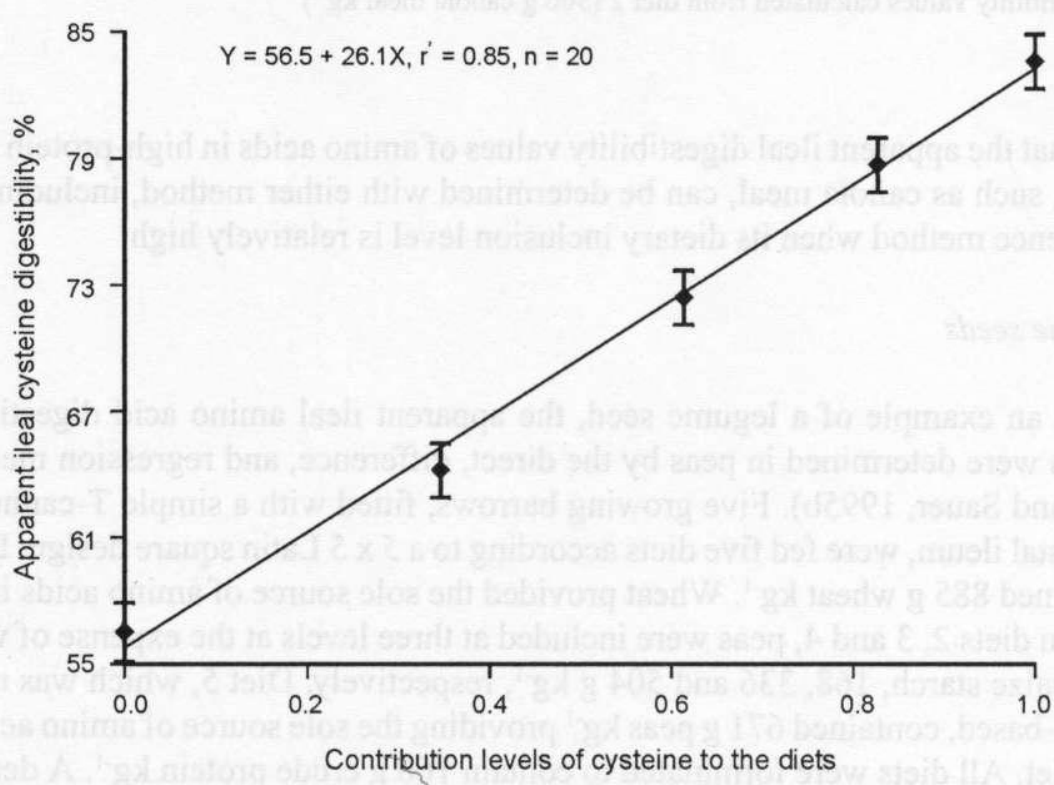

Figure 5. Estimation of the apparent ileal digestibility of cysteine in the assay feed ingredient (peas) by linearly regressing the ileal digestibility values (Y: $\%$, means \pm SE) of cysteine in assay diets against the contribution levels (X: decimal percentage) of cysteine from the basal feed ingredient (wheat) to its content in the assay diets (Fan and Sauer, 1995b) 
As shown in Table 6 , there were no differences $(\mathrm{P}>0.05)$ between the direct, difference, and the regression methods for the determination of apparent digestibilities of amino acids in peas, as illustrated for the indispensable ( + semi-) amino acids. However, the inclusion level of the assay feed ingredient in the assay diet should be high in order to obtain more precise measurements.

TABLE 6 Determination of the apparent ileal digestibility values ${ }^{a}(\%)$ of crude protein and indispensable ( + semi-) amino acids in peas by the direct, the difference and the regression methods (Fan and Sauer, 1995b)

\begin{tabular}{lccc}
\hline \multirow{2}{*}{ Items } & \multicolumn{3}{c}{ Method of detcrmination } \\
\cline { 2 - 4 } & direct method & difference method & regression method \\
\hline Number of observations & 5 & 5 & 20 \\
Crude protein & $75.9 \pm 1.20$ & $75.1 \pm 1.20$ & - \\
& & & \\
Amino acids & & & $89.4 \pm 0.67$ \\
arginine & $89.8 \pm 0.81$ & $90.9 \pm 0.57$ & - \\
histidine & $80.1 \pm 1.08$ & $81.3 \pm 1.12$ & $74.9 \pm 1.36$ \\
isolcucine & $75.2 \pm 1.05$ & $76.9 \pm 2.13$ & $74.8 \pm 1.27$ \\
leucine & $74.9 \pm 1.38$ & $77.0 \pm 1.68$ & $82.5 \pm 0.85$ \\
lysine & $83.5 \pm 1.20$ & $83.8 \pm 0.70$ & $64.9 \pm 1.67$ \\
methionine & $66.3 \pm 1.43$ & $65.3 \pm 1.58$ & $56.5 \pm 1.39$ \\
cysteine & $57.3 \pm 1.27$ & $56.3 \pm 1.91$ & $76.2 \pm 1.04$ \\
phenylalanine & $76.1 \pm 1.55$ & $78.5 \pm 1.23$ & $69.0 \pm 1.35$ \\
tyrosine & $69.5 \pm 1.91$ & $70.2 \pm 1.50$ & - \\
threonine & $68.0 \pm 1.80$ & $69.8 \pm 1.54$ & - \\
valine & $72.8 \pm 1.29$ & $74.5 \pm 1.82$ & \\
\hline
\end{tabular}

a mean and standard error $(n=5)$

b digestibility values calculated from diet $4\left(504 \mathrm{~g}\right.$ peas $\left.\mathrm{kg}^{-1}\right)$

\section{Other feedstuffs}

These include feedstuffs low in protein and/or high in fibre content and those of low palatability.

For some low-protein feedstuffs such as rye, wheat bran, and forage plants, that may be included in diets at limited levels of inclusion, because of poor palatability and/or high fibre content, the determination of amino acid digestibility values is often carried out by the difference method. Kreienbring et al. (1988) reported that the apparent ileal digestibility values of amino acids in forage plants determined by the difference method varied considerably, as indicated by large standard deviations. As the amino acid contents in these forage plants were low and the inclusion levels in the assay diets were also low, the large variation likely resulted from the 
magnifying effect induced by the calculations for determining amino acid digestibility values by the difference method. This magnifying effect was demonstrated by Knabe et al. (1989) in studies with blood meal, which is of low palatability. The ileal digestibility values of isoleucine, the limiting amino acid in blood meal, of three samples of blood meal were $60,70,80 \%$, respectively. As was discussed by Knabe et al. (1989), these values are not indicatives of the variation in ileal amino acid digestibility values of isoleucine among the blood meal samples, as these resulted from a difference of only three percentage units in digestibility values among the diets containing both blood meal and soyabean meal. In these diets, blood meal contributed only $15 \%$ isoleucine to the total dietary isoleucine content. One percentage unit change in the digestibility value in the mixed diet resulted in a corresponding change in the digestibility value of isoleucine of ten percentage units. As was concluded by Knabe et al. (1989), differences in isoleucine digestibility among the blood meal samples may simply be a reflection of experimental errors.

Based on the previous discussion it follows that the regression rather than the difference method should be used to determine amino acid digestibility in feedstuffs such as forage plants and blood meal. As discussed previously, in order to apply the regression method successfully to all amino acids, it is necessary that there are sufficiently large differences in the digestibility values between the assay and basal feed ingredients. This may not always be possible. At least in that case differences should be created with respect to the limiting amino acids in the assay feed ingredients.

\section{Interactions between feedstuffs}

The direct and difference methods are only valid if there are no interactions between the assay and basal feed ingredients. The presence of linear relationships for the majority of amino acids between the assay (peas) and the basal feed ingredient (wheat) showed that there were no interactions in apparent ileal digestibility values of amino acids between these two ingredients (Fan and Sauer, 1995b). There also seemed to be no interactions between barley and canola meal (Fan and Sauer, 1995a). Other studies with pigs, in which the difference method was used, showed that the digestible amino acid supply in a complete diet can be predicted from amino acid digestibility values determined in single feedstuffs, at least for diets composed of barley and soyabean meal or canola meal (Imbeah et al., 1988). Furthermore, studies by Laplace et al. (1989) showed no associative effects between two fibre sources (wheat bran and soyabean hulls) on the ileal digestibility values of most amino acids in a maize starch-based casein diet. Li and Sauer (1994) reported linear increases in the apparent ileal digestibility values of amino acids in a maize starch-based soyabean meal diet when the inclusion level of fat (canola oil) was increased from 3.2 to $12.2 \%$. Although the increases were significant $(\mathbf{P}<0.05)$ 
for all indispensable amino acids, these were of a small magnitude ranging from 1.4 for arginine to 3.6 percentage units for threonine.

The aforementioned studies point to the absence or very small associative effects on ileal amino acid digestibility values between feedstuffs. However, the possibility of associative effects between other feedstuffs should not be completely ruled out. More investigations may be warranted, including feedstuffs with a high content of antinutritional factors. Antinutritional factors, apart from affecting the digestion and/or absorption of protein in the feedstuffs in which these are present, may also affect the utilization of protein in other dietary ingredients. In addition, the digestion and absorption of endogenous protein secreted into small intestine may be affected as well.

\section{CONCLUSIONS}

The ileal rather than faecal analysis method should be used for determining amino acid digestibility values. Values determined with this method reflect the digestive utilization of amino acids in feed ingredients by pigs. Ileal amino acid digestibility values provide an estimate of amino acid availability values and should be used in feed evaluation, and diet formulation.

Apparent ileal amino acid digestibility values reported in the literature, determined with the ileal analysis method, showed considerable variation among different samples of the same feedstuff in name. The variation in ileal amino acid digestibility values within the same feedstuff was reviewed for cereal grains, protein supplements, and legume seeds. In addition to different processing conditions and inherent factors among samples of the same feedstuff, a large proportion of the differences can be attributed to approaches in methodology.

Differences in dietary amino acid levels are likely to be the largest single contributor to the variation of ileal amino acid digestibility values within the same feedstuff. Dietary amino acid levels quadratically affect ileal amino acid digestibility values. In order to remove the effect of dietary amino acid levels, the plateau apparent ileal amino acid digestibility values should be determined.

Methods of determination can also result in differences in ileal amino acid digestibility values within the same feedstuff. In order to eliminate this variation, methods of determination specifically suited for different feedstuffs are recommended. For cereal grains, the regression and the difference method rather than the direct method should be used. In most cases for protein supplements, the direct, the difference and the regression methods are all suited for the determination. However, for feedstuffs including some protein supplements and by-products, that can only be included at low levels in the assay diets, the regression rather than direct or the difference method should be used. 


\section{REFERENCES}

Adeola O., 1996. Bioavailability of tryptophan in soyabean meal for $10-\mathrm{kg}$ pigs using the sloperatio assay. J. Anim. Sci. 74, 2411-2419

Agriculture Research Council, 1981. The Nutrient Requirements of Pigs. Commonwealth Agricultural Bureau, Slough (UK)

Austic R.E., 1983. The availability of amino acids as an attribute of feeds. In: G.E. Robards, R.G. Packham (Editors). Feed Information and Animal Production. Proceedings of the 2nd Symposium of the International Network of Feed Information Centres. Commonwealth Agricultural Bureau, Slough (UK), pp. 175-189

Batterham E.S., 1992. Availability and utilization of amino acids for growing pigs. Nutr. Res. Rev. $5,1-18$

Batterham E.S., Darnell R.E., Herbert L.S., Major E.J., 1986. Effect of pressure and temperature on the availability of lysine in meal and bone meal as determined by slope-ratio assays with growing pigs, rats and chicks and by chemical techniques. Brit. J. Nutr. 55, 441-453

Batterham E.S., Murison R.D., Lewis C.E., 1979. Availability of lysine in protein concentrates as determined by the slope-ratio assay with growing pigs and rats and by chemical techniques. Brit. J. Nutr. 41, 383-391

Buraczewska L., Gdala J., Grala W,, 1989. Ileal digestibility of protein in pigs fed diets with peas of variable content of proteins and tannins. In: J. Huisman, T.F.B. van der Poel, I.E. Liener (Editors). Recent Advances of Research in Antinutritional Factors in Legume Seeds. Pudoc, Wageningen (The Netherlands), pp. 181-184

Buraczewska L., Schulz E., Schröder H., 1987. Ileal digestibility of amino acids in pigs fed barleys differing in protein content. Arch. Anim. Nutr. 37, 861-867

Eggum B.O., 1973. A Study of Certain Factors Influencing Protein Utilization in Feedstuffs in Rats and Pigs. Ph.D. Dissertation. Copenhagen (Denmark)

Fan M.Z., Sauer W.C., 1995a. Determination of apparent ileal amino acid digestibility in barley and canola meal for pigs with the direct, difference, and regression methods. J. Anim. Sci. 73, 2364-2374

Fan M.Z., Sauer W.C., 1995b. Determination of apparent ileal amino acid digestibility in peas for pigs with the direct, difference, and regression methods. Livest. Prod. Sci. 44, 61-72

Fan M.Z., Sauer W.C., 1999. Variability of apparent ileal amino acid digestibility in different pea samples for growing-finishing pigs. Can. J. Anim. Sci. 79, 467-474

Fan M.Z., Sauer W.C., Hardin R.T., Lien K.A., 1994. Determination of apparent ileal amino acid digestibility in pigs: cffect of dietary amino acid level. J. Anim. Sci. 72, 2851-2859

Fan M.Z., Sauer W.C., Li S., 2001. Variability of apparent ileal amino acid digestibility in highprotein wheat samples for growing-finishing pigs. J. Anim. Feed Sci. 10, 103-118

Flis M., Sobotka W., Purwin C., Zduńczyk Z., 1999. Nutritional value of diets containing field beans (Vicia faba L.) seeds with high or low proanthocyadinin leaves for pigs. J. Anim. Feed Sci. 8, 171-180

Gatel F., 1992. Protein quality of legume seeds for monogastrics animals. In: Proceedings of the First European Conference on Grain Legumes, Angers (France), pp. 461-473

Gatel F., Grosjean F., 1990. Composition and nutritive value of peas for pigs. Livest. Prod. Sci. 26, $155-175$

Gdala J., Buraczewska L., Grala W., 1992. The chemical composition of different types and varieties of peas and the digestion of their protein in pigs. J. Anim. Feed Sci. 1, 71-79

Grala W., Jansman A.J.M., van Lecuwen P., Huisman J., van Kempen G.J.M., Verstegen M.W.A., 1993. Nutritional value of fababcans (Vicia faba L.) fed to young pigs. J. Anim. Feed Sci. 2, $169-179$ 
Henry Y., 1985. Principles of protein evaluation in pig feeding. World Rev. Anim. Prod. 21, 48-59

Holmes J.H.G., Bayley H.S., Leadbeater P.A., Horney F.D., 1974. Digestion of protein in the small intestine and large intestine of the pig. Brit. J. Nutr. 32, 479-489

Huisman J., 1989. Antinutritional factors in the nutrition of monogastric farm animals. In: E.J. van Weerden, J. Huisman (Editors). Nutrition and Digestive Physiology in Monogastric Farm Animals. Pudoc, Wageningen (The Netherlands), pp. 17-35

Huisman J., Deuring K., van Leeuwen P., van der Poel A.F.B., Lok J.H., 1988. Experimental technique: Ileal nylon bag digestibility determinations do not predict the negative effects of antinutritional factors in soya and Phascolus Vulgaris beans. In: Proceedings of $5^{\text {th }}$ International Symposium on Protein Metabolism and Nutrition. Publication No. 35. Rostock (GDR), pp. $58-59$

Imbeah M., Sauer W.C., Mosenthin R., 1988. The prediction of the digestible amino acid supply in barley-soyabean meal or canola diets and pancreatic enzyme secretion in pigs. J. Anim. Sci. 66, 1409-1417

Ivan M., Farrell D.J., 1976. Nutritional evaluation of wheat. 5. Disappearance of components in digesta of pigs prepared with two re-entrant cannulas. Anim. Prod. 23, 111-119

Jørgensen H., Sauer W.C., Thacker P.A., 1984. Amino acid availabilities in soyabean meal, sunflower meal, fish meal and meat and bone meal fed to growing pigs. J. Anim. Sci. 58, 926-934

Knabe D.A., 1991. Bioavailability of amino acids in feedstuffs for swine. In: E.R. Miller, A.E. Ulirey, A.J. Lewis (Editors). Swine Nutrition. Butterworth-Heinemann, pp. 327-339

Knabe D.A., LaRue D.C., Gregg E.J., Martinez G. M., Tanksley T.D. Jr., 1989. Apparent digestibility of nitrogen and amino acids in protein feedstuffs by growing pigs. J. Anim. Sci. 67, 441-458

Köhler T., 1992. Evaluation of techniques to collect ileal digesta in pigs. Ph.D. Dissertation. University of Wageningen (The Netherlands)

Laplace J.P., Darcy-Vrillon B., Perez J.M., Henry Y., Giger S., Sauvant D., 1989. Associative effects between two fibre sources on ileal and overall digestibilities of amino acids, cnergy and ccll wall components in growing pigs. Brit. J. Nutr. 61, 75-87

Leterme P., Beckers Y., Théwis L.A., 1990. Trypsin inhibitors in peas: varietal effect and influence on digestibility of crude protein by growing pigs. Anim. Feed Sci. Tech. 29, 45-55

Leterme P., Théwis L. A., Beckers Y., Baudart E., 1990. Apparent and true ileal digestibility of amino acids and nitrogen balance measured in pigs with ileo-rectal anastomosis or T-cannulas, given a diet containing peas. J. Sci. Food Agr. 52, 485-497

Li S., Sauer W.C., 1994. The effect of dietary fat content on amino acid digestibility in young pigs. J. Anim. Sci. 72, 1737-1748

Low A.G., 1982. Digestibility and availability of amino acids from feedstuffs for pigs: a review. Livest. Prod. Sci. 9, 511-520

Mroz Z., Bakker G.C.M., Jongbloed B.A.W., Dekker R.A., Jongbloed R., van Beers A., 1996. Apparent digestibility of nutricnts in diets with different energy densities, as estimated by direct and marker methods for pigs with or without ileo-cecal cannulas. J. Anim. Sci. 74, 403-412

Nyachoti C.M., de Lange C.F.M., McBride B.W., Schulze H., 1997. Significance of endogenous gut nitrogen losses in the nutrition of growing pigs: A review. Can. J. Anim. Sci. 77, 149-163

Owsley W.F., Knabe D.A., Tanksley T.D. Jr., 1981. Effect of sorghum particle size on digestibility of nutrients at the terminal ileum and over the total digestive tract of growing-finishing pigs. J. Anim. Sci. 52, 557-566

Sauer W.C., Dugan M., De Lange C.F.M., Imbeah M., Mosenthin R., 1989. Considerations in methodology for the determination of amino acid digestibilities in feedstuffs for pigs. In: M. Friedman (Editor). Absorption and Utilization of Amino Acids. Vol. III. CRC Press, Boca Raton, FL, pp. $217-230$ 
Sauer W.C., Fan M.Z., Mosenthin R., Droclnner W., 2000. Methods for measuring ileal amino acid digestibility in pigs. In: J.P.F. D'Mello (Editor). Farm Animal Metabolism and Nutrition. CABI Publishing, CAB International, Wallingford, Oxon (UK), pp. 279-306

Sauer W.C., Kennelly J.J., Aherne F.X., Cichon R.M., 1981. The availabilities of amino acids in barley and wheat for growing pigs. Can. J. Anim. Sci. 61, 793-802

Sauer W.C., Ozimek L., 1986. Digestibility of amino acids in swine: results and their practical application. A review. Livest. Prod. Sci. 15, 367-387

Sauer W.C., Stothers S.C., Parker R., 1977b. Apparent and true availabilities of amino acids in wheat and milling by-products for growing pigs. Can. J. Anim. Sci. 57, 775-784

Sauer W.C., Stothers S.C., Philips G.D., 1977a. Apparent availabilities of amino acids in maize, wheat and barley for growing pigs. Can. J. Anim. Sci. 57, 585-597

Sibbald I.R., 1987. Estimation of bioavailable amino acids in feedingstuffs for poultry and pigs: a review with emphasis on balance experiments. Can. J. Anim. Sci. 67, 221-300

Tanksley T.D. Jr., Knabe D.A., 1984. Ileal digestibilities of amino acids in pig feeds. In: W. Haresign, D.J.A. Cole (Editors). Recent Advances in Animal Nutrition. Butterworth, London, pp. 75-94

Wünsche J., Herrmann U., Meinl M., Hennig U., Kreienbring F., Zwierz P., 1987. Einfluß exogener Faktoren auf die präzäkale Nährstoff- und Aminosäurenresorption, ermittelt an Schweinen mit Ileo-Rektal-Anastomosen. 1. Mitteilung. Einfluss des Zerkleinerungsgrades von Getreide. Arch. Anim. Nutr. $37,745+764$

\section{STRESZCZENIE}

\section{Zmienność strawności aminokwasów u świń: czynniki związane z paszą i metodą oznaczania}

W literaturze znajduje się dużo danych dotyczących pozornej strawności jelitowej aminokwasów w paszach dla świń. Oprócz różnic w strawności jelitowej aminokwasów między poszczególnymi paszami, zaskakująco duże różnice występują między strawnością oznaczoną w różnych próbach nominalnie tej samej paszy. Zmienność tę powodują różne warunki technologiczne i inne czynniki różnicujące próby tej samej paszy, jednak czȩść zmienności można przypisać różnym metodom oznaczania strawności aminokwasów. Należy pamiętać, że na wartość współczynników strawności aminokwasów mogą wpływać różne czynniki, jak stosowana metoda kolckcji treści z jclita biodrowego, $\mathrm{i}$ inne, zależne od badanej paszy. Jednym z czynników metodycznych wpływających na strawność jelitową aminokwasów tej samej paszy są różnice w zawartości aminokwasów w paszy. Poziom aminokwasów w diecie wpływa na strawność jelitową aminokwasów w sposób krzywoliniowy. Dlatego w celu wyeliminowania tego wpływu strawność jelitową aminokwasów powinno się oznaczać przy poziomic, w którym nie ma już zależności między zawartością aminokwasów a ich strawnością (poziom ,plateau”). Na strawność jelitową tej samej paszy mogą także wpływać metody jej oznaczania, tj. bezpośrednia, różnicowa lub regresyjna. W celu wyeliminowania tej zmienności zaleca się oznaczanie strawności metodami dopasowanymi do poszczególnych rodzajów pasz. Wszystkie te omówione czynniki należy brać pod uwage przy wykorzystywaniu danych z literatury jako podstawy układania diet dla świń. 